\title{
ARBOREAL LICHENS ON A SAGEBRUSH BRANCH IN SOUTHWESTERN SASKATCHEWAN
}

BERNARD DE VRIES, 29 Hogan Place, White City, SK S4L 1C1

\section{Introduction}

The purpose of this paper is to document the occurrence of 15 lichen species growing on an isolated, dead and weathered branch of Hoary Sagebrush (Artemesia cana), a common shrub on open prairie.

The branch was approximately $37.5 \mathrm{~cm}$ long, with two small side branches, and averaged $7.5 \mathrm{~mm}$ in thickness (Figure 1). It was found on sparsely vegetated earth in lightly grazed native grasslands a few meters from live bushes of Hoary Sagebrush and Shrubby Cinquefoil (Potentilla fruiticosa). The site was estimated to be one $\mathrm{km}$ from Skull Creek to the west and Bridge Creek to the east, in E 2-10-22-W3. The area is about
$22 \mathrm{~km}$ northeast of Cypress Hills East Block on predominantly native fescue prairie in the Mixed Grassland Ecoregion as part of the Prairie Ecozone (Map 1). ${ }^{1}$ The branch was collected on June 13, 1999, during a field excursion to the Wolfater's ranch in conjunction with Native Prairie Appreciation Week.

The distribution of the lichens (indicated by the number at the end of each description below) is shown in Figure 1, and the following annotated list summarizes these lichens. The lichens have been identified by the author, and scientific names and authors follow Esslinger. ${ }^{9}$ Vernacular names are those of Brodo et al, and Goward., 10

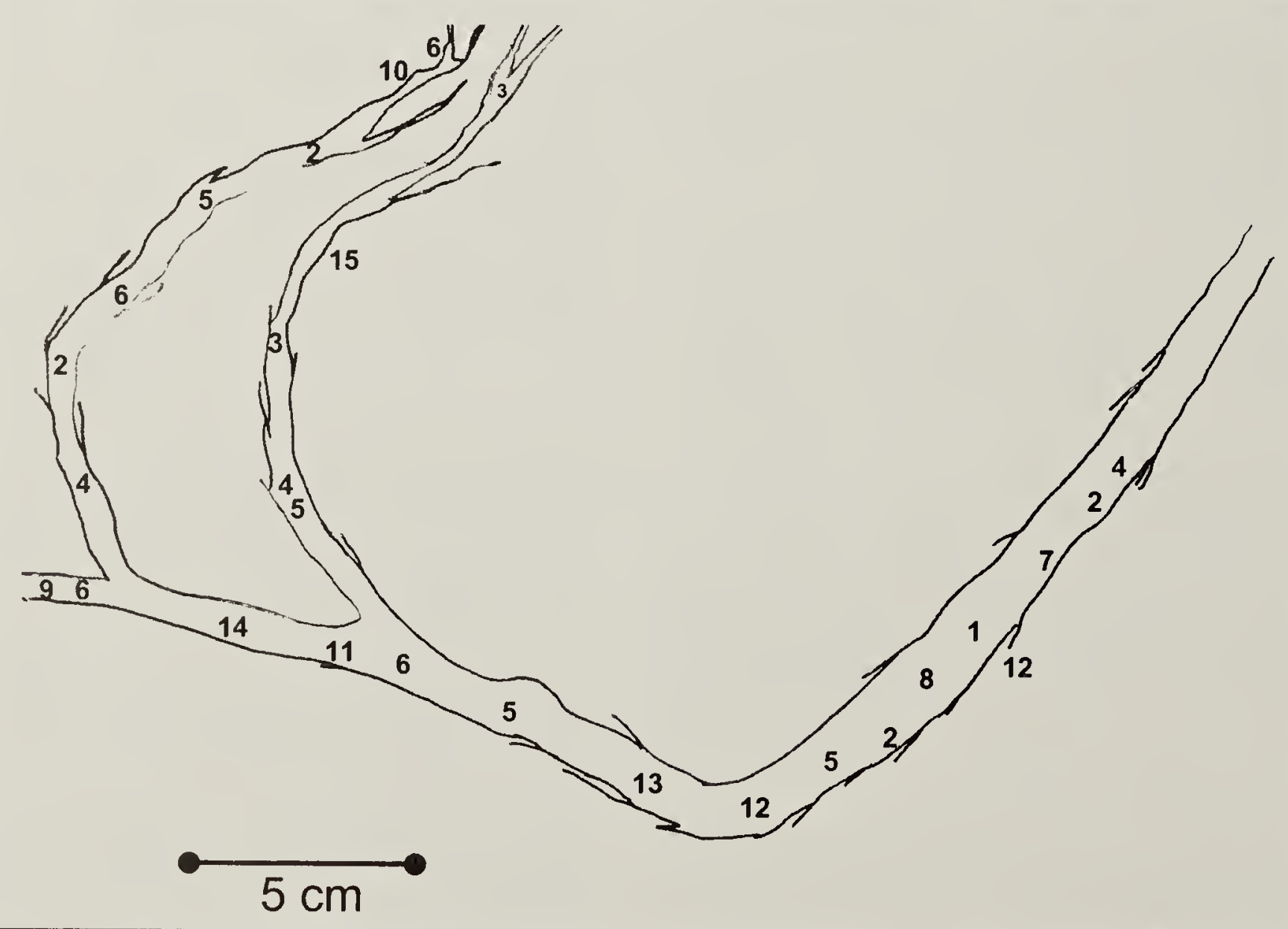

Figure 1. Sagebrush branch showing the locations of lichens referred to by numbers given in the annotated list. 


\section{Annotated Lichen List}

Amandinea punctata (Hoffm.) Coppins and Scheid. (Tiny button lichen). Found twice on shreddybark as small specimens. This species ranges widely throughout North America, occurring on various types of bark and wood. (\#12)

Bryoria simplicior (Vainio) Brodo and D. Hawksw. (Spangled horsehair lichen). Found once with Physcia adscendens on the upper bark. The species is northern boreal in distribution, but is also recorded for the Cypress Upland Ecoregion. ${ }^{6,11}$ (\#14)

Hypogymnia austerodes (Nyl.) Raesaenen (Varnished tube lichen). Found once on weathered wood terminating a side branch. This lichen has been recorded for the Cypress Upland Ecoregion in southwestern Saskatchewan. ${ }^{3}$ (\#10)

Hypogymnia physodes (L.) Nyl. (Monk'shood lichen). Found in four separate locations on the upper bark, where it is associated with Parmeliopsis hyperopta (Gray starburst lichen) in one location only (Figure 1). It is one of the most common and widespread tree lichens in the boreal forest, extending southward into the montane coniferous forest. It is considered rare in the Aspen Parkland but occurs in the Cypress Upland Ecoregion. ${ }^{3,11}$ (\# 6)

Lecanora pulicaris (Pers.) Ach. (Blackeyed rim-lichen). A small arboreal crustose lichen found once on shreddy bark. The species occurs throughout the boreal forest and has been recorded for the Aspen Parkland and Cypress Upland ecoregions as Lecanora coilocarpa (Ach.) Nyl. 2,12 (\# 7)

Lecanora symmicta (Ach.) Ach. (Fused rim-lichen). This small, tree-dwelling crustose lichen was found once on upper shreddy bark. The species is widespread in the boreal forest and its preference for open locations fits the discovery site. It has been recorded for the Cypress Upland Ecoregion., ${ }^{312}$ (\#13)
Melanelia exasperatula (Nyl.) Essl. (Lustrous camouflage lichen). Found only once on upper bark. The species occurs in all ecozones and has been recorded for the Cypress Upland Ecoregion. ${ }^{3,6}$ (\#1)

Parmelia sulcata Taylor (Hammered shield lichen). Distributed over the upper side of the first side branch in three scattered locations in association with Physcia aipolia, (Hoary rosette lichen). The species is widespread in all four ecozones and is a pioneer species on various substrates. ${ }^{3,5}$ (\# 4)

Parmeliopsis hyperopta (Ach.) Arnold (Gray starburst lichen). Found only once on the upper bark, where it is associated with Hypogymnia physodes (Monk's-hood lichen). It is found in the northern boreal forest (Taiga and Boreal Shield ecozones) and scattered in the Aspen Parkland. It also occurs in the Cypress Upland Ecoregion.,11 (\#9)

Physcia adscendens (Fr.) H. Olivier (Hooded rosette lichen). Scattered over shreddy bark in four locations. This common species ranges throughout all four ecozones including the Cypress Upland Ecoregion, ${ }^{6}$ and is commonly found on bark of a variety of trees or tall shrubs. It has been found on mature Manitoba Maple (Acer negundo var. interius) and Balsam Poplar (Populus balsamifera) in prairie coulees and ravines as well as in the Aspen Parkland. ${ }^{3,4.7 .8}$ (\#2)

Physcia aipolia (Ehrh. ex Humb.) Fuernr. (Hoary rosette lichen). Found scattered on the upper branch in four locations and once in association with Parmelia sulcata (Hammered shield lichen). Commonly found in all ecozones on bark and wood of various trees and tall shrubs preferring open locations. It has been recorded for prairie coulees on mature trees and for the Aspen Parkland as well as the Cypress Upland Ecoregion., ${ }^{3,7.8}$ (\#5)

Usnea hirta (L.) F.H. Wigg. (Bristly beard 
lichen). Found once as a fairly large specimen on the upper and weathered terminal main branch. This is a common species ranging throughout all four ecozones and in the Cypress Upland Ecoregion. ${ }^{5.6}$ It is typically found on hard, weathered wood such as old fence posts or boards. ${ }^{3,46}$ (\#11)

Usnea substerilis Mot. (Embossed beard lichen). Found as a very small immature specimen on shreddy bark. The species has been recorded for the northern and central boreal forest, and the Cypress Upland Ecoregion. ${ }^{6.11}$ (\#15)

Xanthoria hasseana Raesaenen (Poplar sunburst lichen). Found twice as small specimens on an upper terminal branch. This lichen has been recorded across central and southern regions with no records to date from Cypress Upland Ecoregion. ${ }^{3}$ (\#3)

Unidentified crustose species found once on shreddy bark. (\#8)

\section{Discussion}

Lichen diversity on alive or dead, attached or isolated branches or twigs, is not uncommon in forested areas. This particular branch showed an unusual diversity of lichens with a boreal affinity found in all ecozones (with the exception of Bryoria simplicior, Hypogymnia austerodes, Lecanora pulicaris, and Xanthoria hasseana). Unfortunately time did not permit a survey of other Hoary Sagebrush or other shrubs in the immediate vicinity for other occurrences of these lichens, nor to investigate the two creeks for possible arboreal lichen on trees. The author has not found these particular lichens previously on Hoary Sagebrush, and considers their presence at this locality to be rare, although future surveys of Hoary Sagebrush might prove otherwise.

How these lichens arrived at this particular location and branch is difficult to answer. Assuming that the entire branch with lichens was not transported to the site by physical or mechanical means (cattle, farm implements, strong winds, persons), the most likely explanation would be that they were transported by recent aerial fragmentation from the east end of the Cypress Upland Ecoregion or the adjacent wooded prairie coulees as the nearest dispersal sources. The fact that these lichens did not form well integrated communities, such as those found on well established

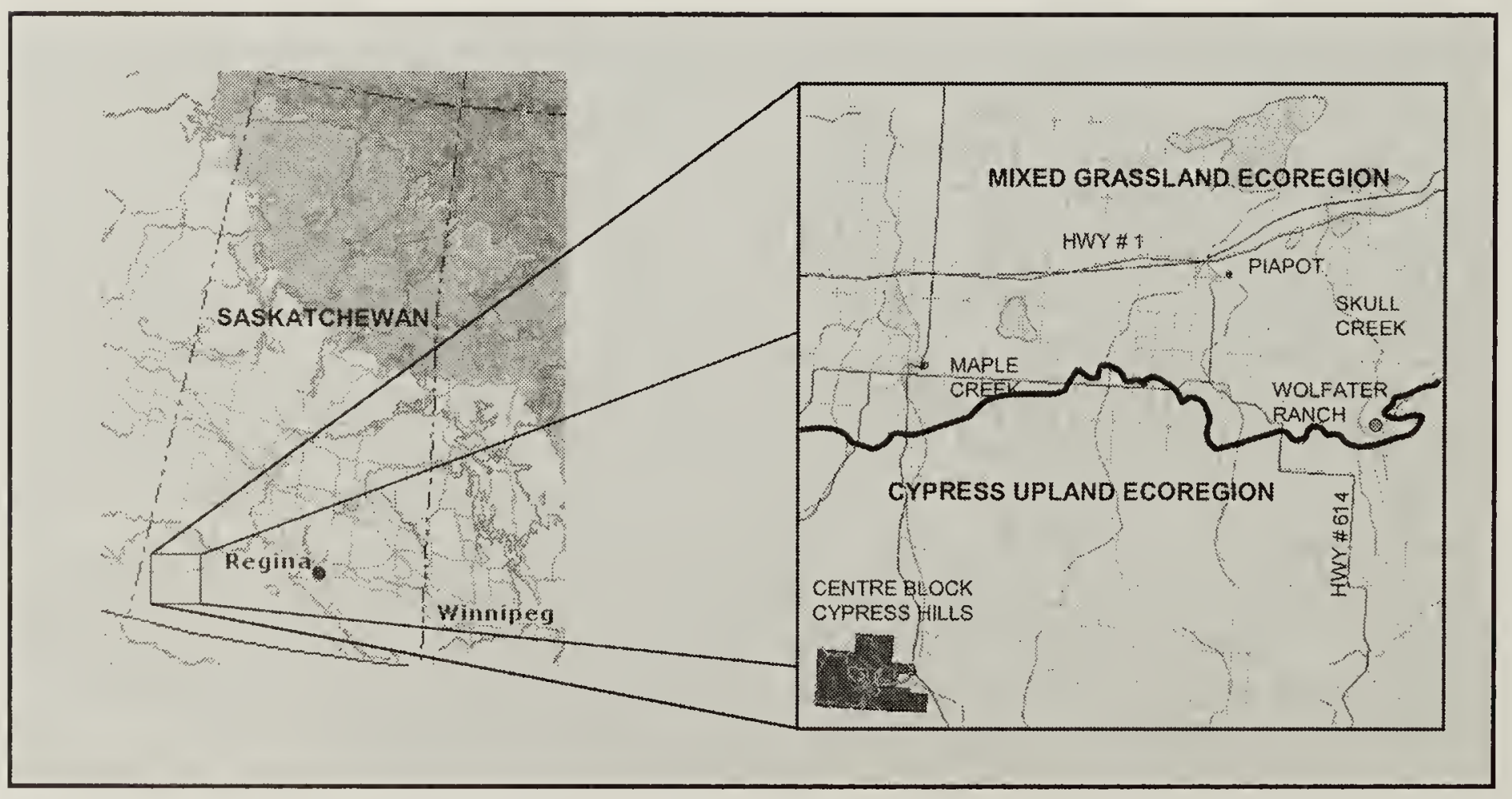

Map 1. Location of the sagebrush collection site 
locations on mature tree bark, but occurred mostly singly, suggests recent colonization of the branch. The lichens are quite small, not exceeding 1 to $2 \mathrm{~cm}$ in diameter, suggesting slow growth under a more dry climatic regime than found in the boreal forest. An exception is Usnea hirta (Bristly beard lichen) which measured about $4.5 \mathrm{~cm}$ in diameter.

\section{Acknowledgements}

The Author is much indebted to Robert A. Wright, Plant Ecologist, Saskatchewan Environment for his interest in this paper, and many helpful suggestions, as well as preparing the figures. Thanks are also due to my wife Irma for her enthusiastic assistance in fieldwork, support and encouragement in preparing the manuscript.

1. ANONYMOUS. 1974. Surveys and Mapping Branch Department of Energy, Mines and Resources. Regina, Saskatchewan.

2. BIRD, C.D. 1972. A Catalogue of the Lichens reported from Alberta, Saskatchewan and Manitoba. Mimeograph. Department of Biology, University of Calgary, Alberta.

3. BRODO, I.M., S.D. SHARNOFF, and S. SHARNOFF. 2001. Lichens of North America. Yale University Press, New Haven.
4. de VRIES, B. Lichens of the Qu'Appelle Valley. Unpublished manuscript.

5. de VRIES, B. 1999-2001. Forest Ecosystem Classification Survey. Unpublished lichen lists.

6. de VRIES, B. 2000. Forest Ecosystem Classification Survey, series 3 \& 4, Cypress Upland Ecoregion. Unpublished computerized lichen list.

7. de VRIES, B. 2002. Lichen Inventory of the Van Brienen Land Nature Sanctuary. Report prepared for Nature Saskatchewan.

8. de VRIES, B. 2003. Lichen Inventory of the Crooked Lake Fen Nature Sanctuary. Blue Jay 61:43-50.

9. ESSLINGER, T.L. 1997. A cumulative checklist for the lichen-forming lichenicolous and allied fungi of the continental United States and Canada. North Dakota State University, Fargo, North Dakota. http:/ /www.ndsu.nodak.edu/Instruct/esslinge/chcklst/ chcklst7.htm.

10. GOWARD, T., B. MCCUNE, and D. MEIDINGER. 1994. The Lichens of British Columbia. Part 1. Foliose and Squamulose Species. Research Program, Ministry of Forests, Victoria, B.C.

11. THOMSON, J.W. 1984. Arctic American Lichens. 1. The Macrolichens. Columbia University Press, New York.

12. THOMSON, J.W. 1984. Arctic American Lichens. 2. The Macrolichens. University of Wisconsin Press.

"Xanthoparmelia chlorochroa has proved to be a reliable indicator of excellent antelope habitat and has been used as such by wildlife managers reintroducing antelope to certain areas in the Great Basin. The lichen is eaten by antelope and is especially important in early spring and under drought conditions. Xanthoparmelia chlorochroa is highly prized by the Ramah Navajo of New Mexico, and by craftspeople in other parts of the west, as a source of boiling-water dyes for reddish brown colors." Brodo, Sharnoff and Sharnoff, Lichens of North America, p. 734 


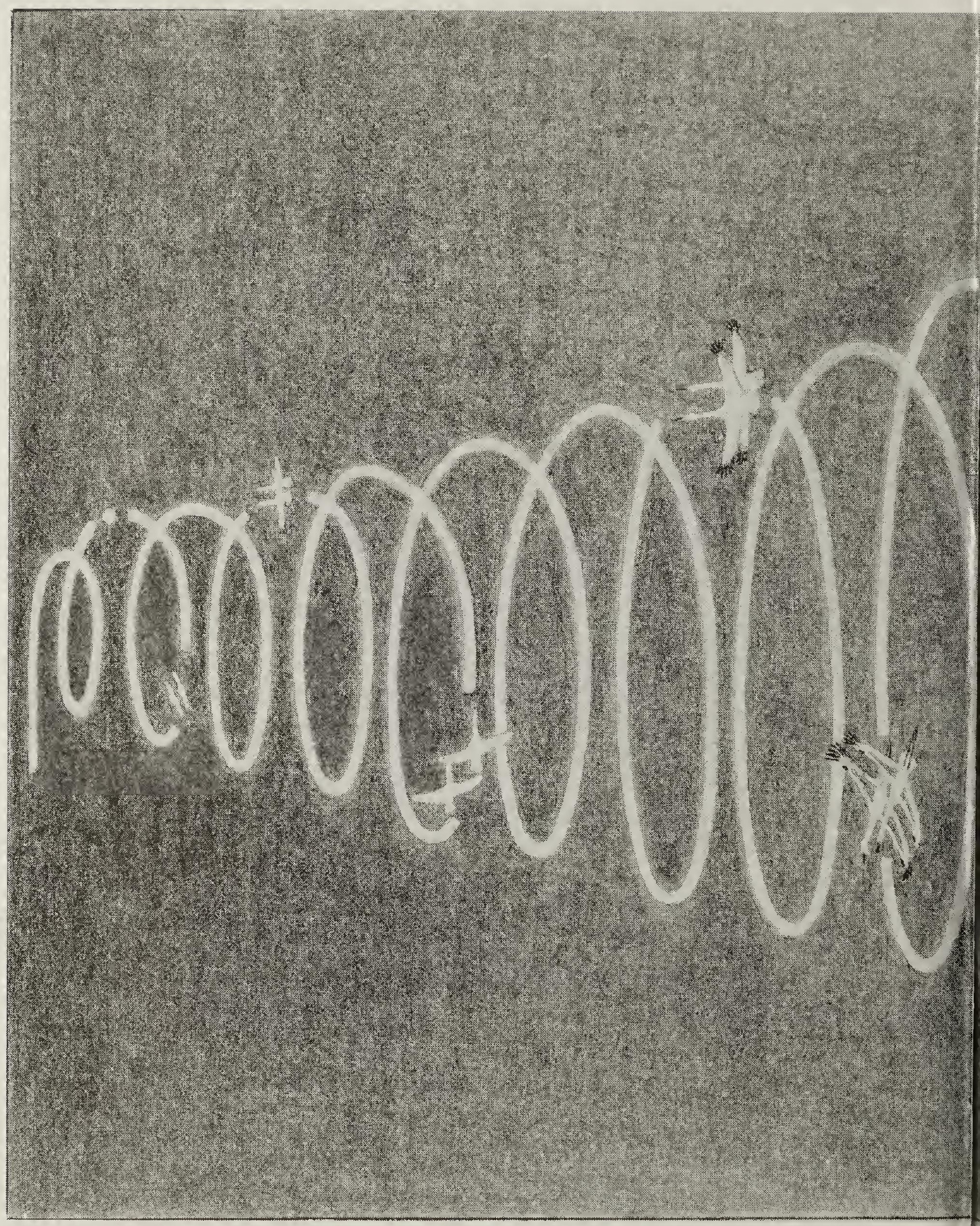




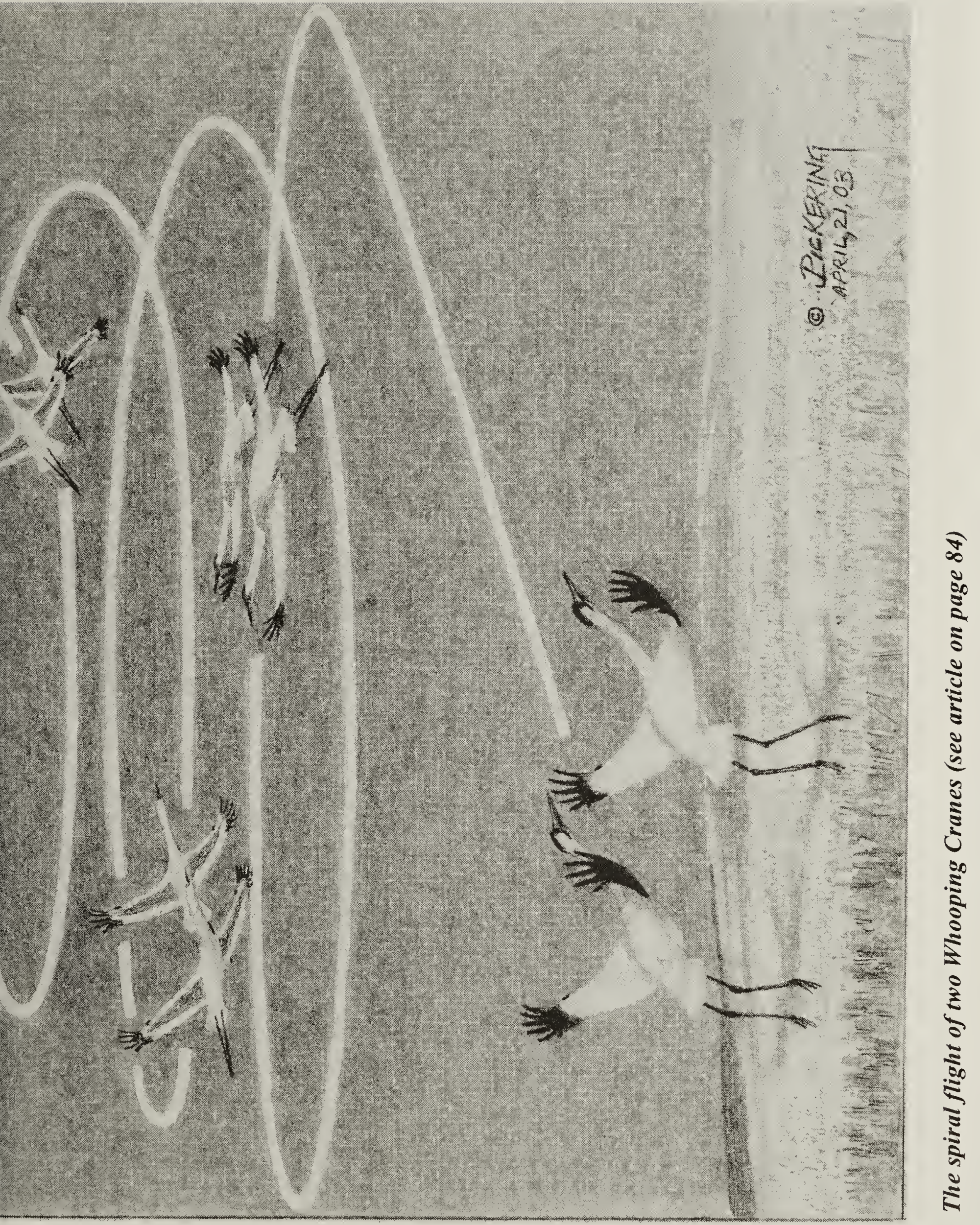

